Plant Tissue Cult. \& Biotech. 24(1): 37-45, 2014 (June)

$\overline{\text { PTC\&B }}$

\title{
An Improved System for Rapid in vitro Regeneration of Saintpaulia ionantha
}

\section{Zahra Ghorbanzade* and Mohammad Ahmadabadi}

Department of Biotechnology, Faculty of Agriculture, Azarbaijan Shahid Madani

University, $35 \mathrm{~km}$ Tabriz-Maraqeh Road, Tabriz, Iran

Key words: Saintpaulia ionantha, Improved system, In vitro regeneration

\begin{abstract}
For rapid multiplication and genetic manipulation of African violets (Saintpaulia ionantha Wendl.) was aimed at developing a rapid and efficient regeneration and adaptation system from leaf explants. Using RM medium supplemented with different combinations of growth regulators, we developed a highly efficient and time-saving in vitro regeneration protocol. The developed system was also successfully applied for plant regeneration from petiole and internode explants of several Saintpaulia cultivars at a high efficiency. Regeneration occurred through both somatic embryogenesis and shoot organogenesis at a high frequency. Also, we developed a rapid root formation protocol followed by their efficient adaptation for in vitro regenerated plantlets.
\end{abstract}

\section{Introduction}

African violet (Saintpaulia ionantha Wendl.) is an economically important ornamental plant with many varieties with diverse colors and shapes. Propagation of African violet through traditional method of leaf cuttings is highly time-consuming. Also, a limited number of plants are produced through this method and therefore, development of a rapid propagation method of this plant species will be of a great economic benefit in ornamental plant industry. One of the best methods for rapid plant propagation is in vitro culture technology that enables fast multiplication of plants in a short time and limited space. So far, successful plant regeneration from different parts of the African violets has been reported in leaves (Cooke 1977, Daud et al. 2008, Mithila et al. 2003, Shukla et al. 2013, Smith and Norris 1983, Start and Cumming 1976, Sunpui and Kanchanapoom 2002), anther (Weatherhead et al. 1982), sub-epidermal tissue

*Author for correspondence: <m.ahmadabadi@azaruniv.edu>. 
(Bilkey and Cocking 1981), protoplasts (Hoshino et al. 1995, Winkelmann and Grunewaldt 1995), petioles (Mithila et al. 2003, Sunpui and Kanchanapoom 2002) and floral buds (Daud and Taha 2008, Molgaard et al. 1991). However, most of the methods are largely time-consuming and in several cases, regenerated plants lose their flowering competence (Daud and Taha 2008, Daud et al. 2008). Also, in most of the protocols for in vitro propagation of African violets, shoot regeneration has been considered as the most important step, however, successful root induction and uninterrupted robust growth are critical for rapid and efficient plant hardening and adaptation. It is, therefore, necessary to optimize in vitro regeneration systems for rapid and efficient shoot and root induction with no significant effects on the plant phenotype. Several factors are involved in optimizing a tissue culture system; therefore, that the combination of appropriate concentrations of plant growth regulators is considered as the most important one. In this study, we aimed at developing a rapid shoot regeneration and subsequent root formation system for efficient multiplication of African violets from leaf and petiole segments.

\section{Materials and Methods}

Five local cultivars of Saintpaulia ionantha Wendl. from Guilan province, Iran were used in this experiment. For surface sterilization, plant materials were washed under running tap water and disinfected with $70 \%$ ethanol for $30 \mathrm{sec}$ followed by incubation in 5\% sodium hypochlorite for $15 \mathrm{~min}$. The plant segments were then washed with sterile water under aseptic conditions and cultured on MS.

For leaf culture, leaves of young sterile plants were cut in about $3 \times 3 \mathrm{~mm}$ pieces. Leaf segments were then cultured on RM medium (Linsmaier and Skoog 1965) complemented with $30 \mathrm{~g} / \mathrm{l}$ sucrose and different combinations of hormones for shoot induction (Table 1). In addition, MS supplemented with different plant growth regulators has been evaluated for shoot elongation as well for root formation and growth from in vitro regenerated shoots. Petioles of sterile leaves were cut into about $1 \mathrm{~mm}$ pieces followed by culturing with the basal side on desired media. Three $\mathrm{mm}$ long root sections of sterile plants were cultured on the optimized medium.

The $\mathrm{pH}$ was adjusted to 5.8 and the media were solidified by adding $7 \mathrm{~g} / \mathrm{l}$ agar-agar (HIMEDIA-India). thidiazuron (TDZ) and GA3 were filter-sterilized $(0.2 \mu \mathrm{m}$, Whatman, UK) and added to the medium after autoclaving.

Cultured plates were incubated in growth chamber under a diurnal cycle of $16 \mathrm{hrs}$ light of $25 \mu \mathrm{E} / \mathrm{m}^{2} / \mathrm{s}$ at $25^{\circ} \mathrm{C}$ followed by an $8 \mathrm{hrs}$ dark period at $22^{\circ} \mathrm{C}$. After four - six weeks (without subculture) regeneration was evaluated and data were 
noted. The adopted experimental design was completely randomized with three replicates. The statistical comparison was performed by one-way ANOVA using SPSS software version 19.0, and means were compared using the Duncan's test ( $\mathrm{p}$ $<0.05)$.

\section{Results and Discussion}

For rapid and efficient shoot regeneration and subsequent root formation a protocol for African violets (Saintpaulia ionantha Wendl.) was developed. Shoot induction in in vitro culture usually requires the exogenous application of growth regulators such as auxin and cytokinin (Riou-Khamlichi et al. 1999). In African violet, application of zeatin (Daud et al. 2008), BAP (Daud and Taha 2008, Sunpui and Kanchanapoom 2002) and TDZ (Mithila et al. 2003, Shukla et al. 2013) have been reported to play an important role in in vitro shoot regeneration. However, most of the experiments have been carried out using MS basal medium. Our initial studies using two basic media including MS and Revised-MS (RM) (Linsmaier and Skoog 1965), fortified with $1 \mathrm{mg} / \mathrm{l} \mathrm{BAP}$ and $1 \mathrm{mg} / \mathrm{l} \mathrm{NAA}$ indicated that the RM basic medium is more suitable for African violet regeneration (data not shown). Therefore, all other experiments for shoot regeneration were performed using RM basic medium. To find out the best hormonal combination and concentration for shoot induction from leaf discs, we tested different concentrations of BAP and TDZ in combination with NAA (Table 1) on shoot regeneration from $0.3 \mathrm{~cm}^{2}$ leaf fragments of African violet in RM basal medium. Results showed that shoot induction on TDZ-containing media starts about two
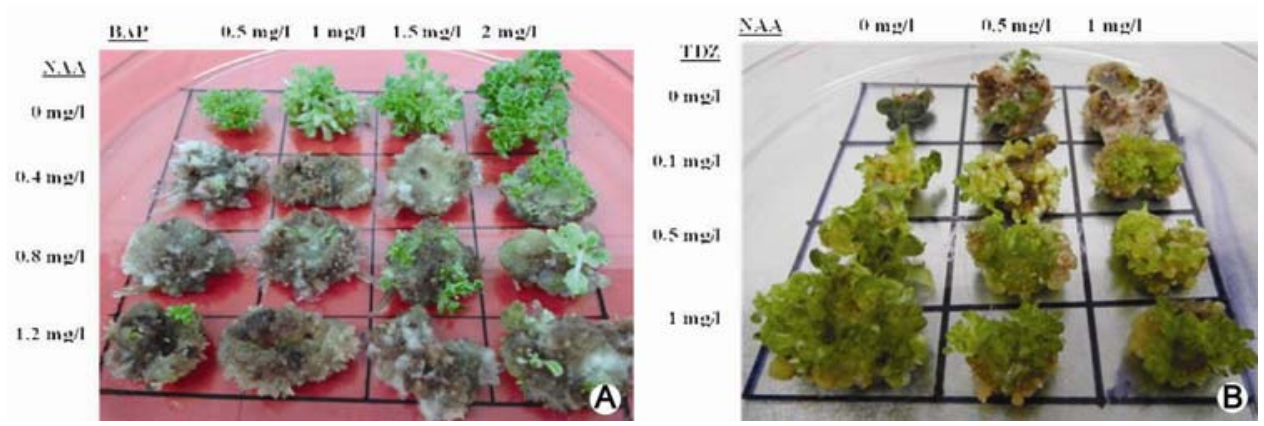

Fig. 1. In vitro regeneration response of $S$. ionantha leaf tissues cultured on different media containing various combinations of NAA and BAP (A) or NAA and TDZ (B).

weeks earlier than BAP-containing media. The highest shoot induction rate (100\%) was also observed on medium containing $1 \mathrm{mg} / 1 \mathrm{TDZ}$ (Table 1 and Figs 1 and $2 \mathrm{~A}$ ). It should be mentioned that on BAP containing media, regeneration occurred mainly through direct organogenesis, while the addition of TDZ promoted somatic embryogenesis (Fig. 1). 
In general, in both experiments, NAA application resulted in a dosedependent callus induction (Table 1, Fig. 1). The calli on BAP-containing media were largely non-embryogenic with a high tendency to root formation (Fig. 1A), while the calli produced on TDZ-containing media were mainly embryogenic with ability to generate shoots over the time (Fig. 1B).

Taking all important parameters including regeneration rate and frequency into account (Table 1 and Fig. 1), RM medium supplemented with $1 \mathrm{mg} / \mathrm{l} \mathrm{TDZ}$ has been recognized as the best medium for rapid and efficient shoot induction (Fig. 2A). We have tested this medium for shoot regeneration from petiole, internode and root explants. High efficiency rapid regeneration was obtained from petiole and internode explants. The results were comparable to those obtained from leaf explants (Fig. 2B and data not shown). However, for root explants, plant regeneration occurred through callus induction with lower efficiency (50\%) (Data not shown). Also, the same protocol has been successfully used for shoot regeneration from at least five varieties of African violets. Similar high shoot regeneration rates were observed for all varieties, indicating genotype-independency of the developed protocol (Data not shown).
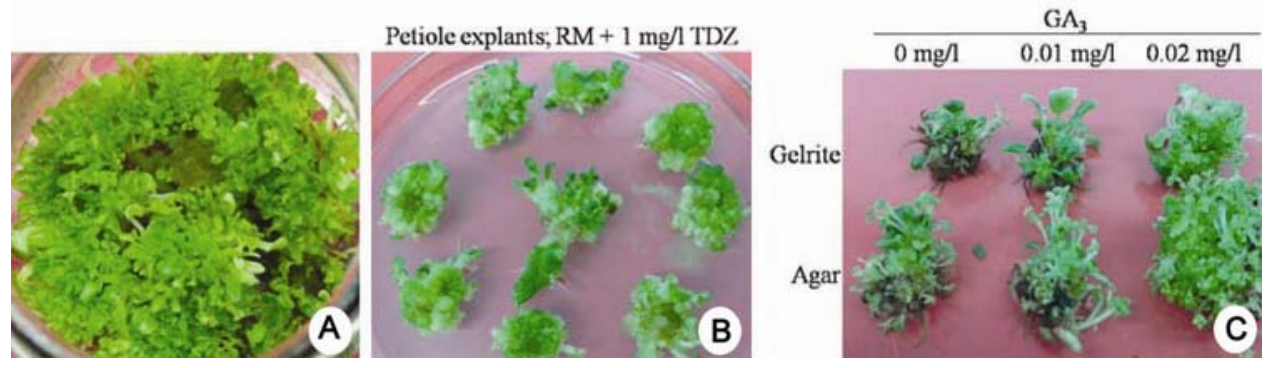

Fig. 2. In vitro regeneration response of $S$. ionantha from leaf (A) and petiole (B) explants cultured on RM $+1 \mathrm{mg} / \mathrm{l} \mathrm{TDZ}$ after six and four weeks, respectively. (C) The effects of added $\mathrm{GA}_{3}$ in the MS on shoot multiplication and elongation of regenerated plantlets are shown. Two different gelling agents, gelrite and agar, were tested in this experiment.

Application of $\mathrm{GA}_{3}$ in the culture media has been reported to have different effects on shoot and root induction and elongation. In tobacco, for example, addition of $\mathrm{GA}_{3}$ has led to irreversible repression of shoot formation (Thorpe and Meier 1973). In buckwheat, $\mathrm{GA}_{3}$ application has resulted in accelerated root initiation and increased root number (Srejović and Nešković 1985). Positive effects of $\mathrm{GA}_{3}$ on shoot induction and elongation have also been reported in ginger (Lincy and Sasikumar 2010), Cocos nucifera L. (Montero-Cortes et al. 2010), Tylophora indica (Sahai et al. 2010) and Peperomia (Ahmadabadi and Bock 2010). Therefore, we tested low concentrations of $\mathrm{GA}_{3}$ for its effects on in vitro 
regenerated shoots of African violet. The results showed that GA3 has positive effects on shoot multiplication of African violet cultures; however, shoot elongation as well as root formation have not been affected significantly (Fig. 2C).

Rapid root induction and elongation is one of the most important steps toward fast and successful production of in vitro regenerated shoots. However, this issue has not been considered in most of the protocols developed for in vitro propagation of African violets. We, therefore, aimed at developing a reliable root induction and an elongation system for in vitro regenerated shoots of African violets. Incubation of regenerated shoots on hormone free MS or half strength of MS did not result in efficient root induction (Fig. 3A). As auxins are well known to induce root induction (Verstracten et al. 2013), different concentrations of IAA

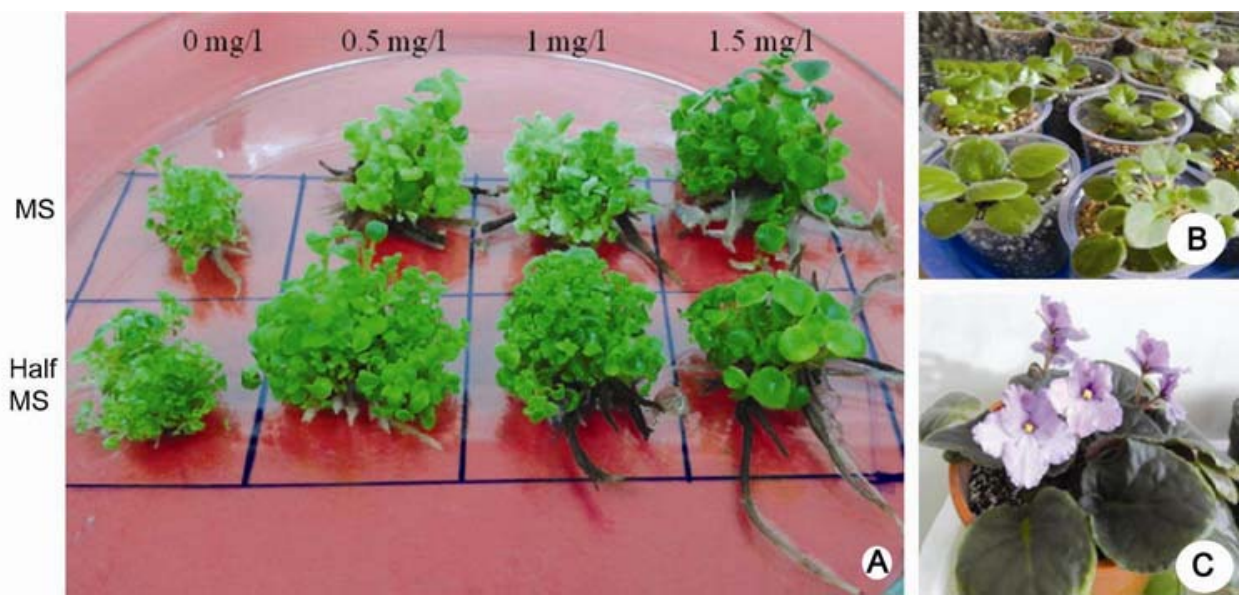

Fig. 3. Effects of four concentrations of IAA on root induction and elongation from in vitro regenerated shoots of Saintpaulia in MS or half strength of MS after four weeks of culture (A). A number of acclimated plants and one plant in flowering are respectively, shown in Fig. (B) and (C).

were tested for their effects on root formation from regenerated shoots (Table 1). The results showed that highly efficient $(100 \%)$ root induction and growth occurs on half strength of MS fortifed with $1.5 \mathrm{mg} / \mathrm{l} \mathrm{IAA} \mathrm{(Table} \mathrm{1,} \mathrm{Fig.} \mathrm{3A).} \mathrm{Note} \mathrm{that}$ shoots grown in this medium were more suitable for transfer into the soil for hardening (Figs. 3A, B). Rooted plantlets were successfully transferred to soil at a high efficiency $(95 \%$, Fig. 3B) followed by normal plant growth and flower development (Fig. 3C). 


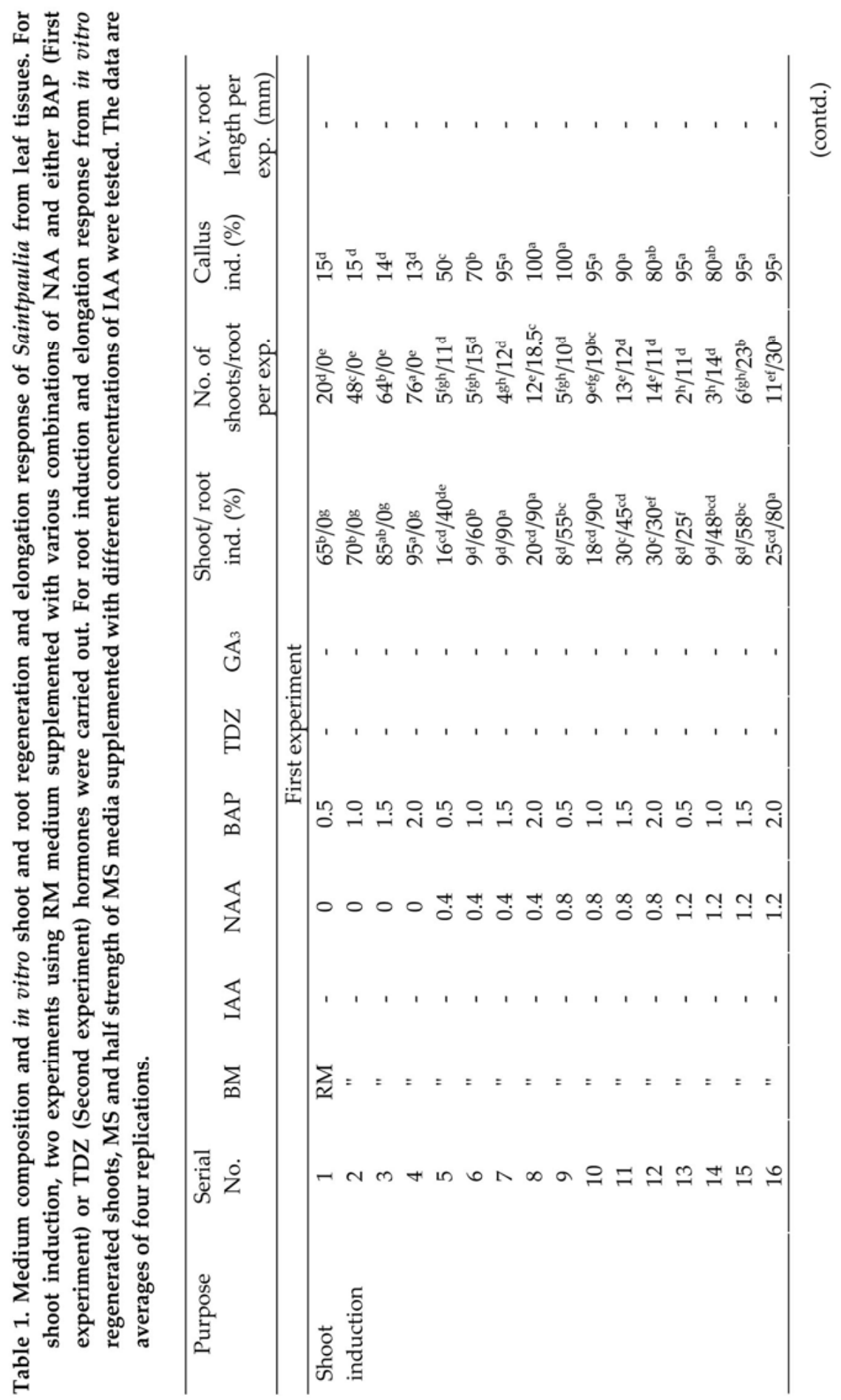




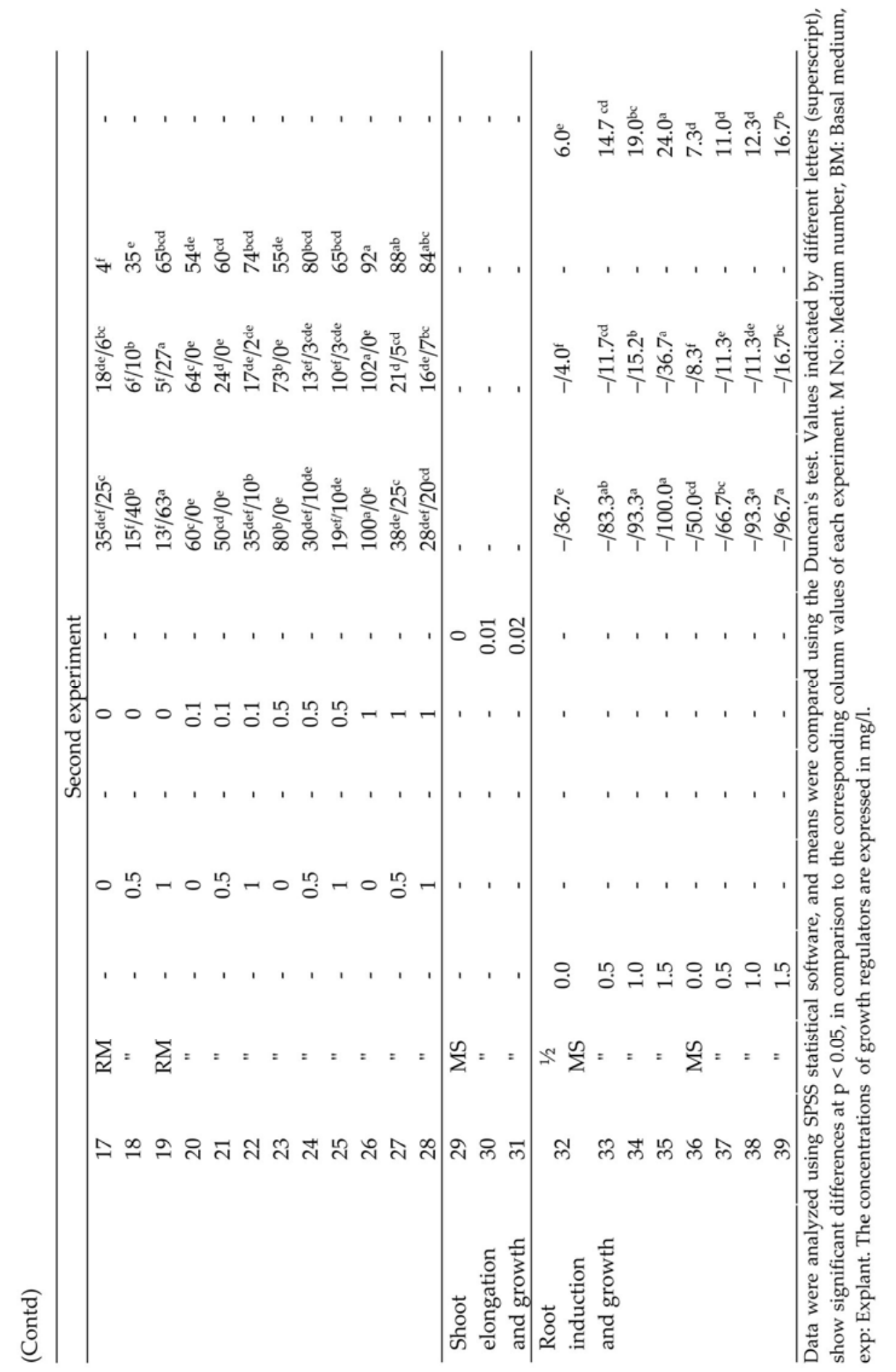


The whole procedure from sterile leaf culture to plant hardening takes around 11 - 12 months. No visible phenotypic difference was observed among regenerated plants during this period. However, longer incubation on regeneration medium and repeated rounds of regeneration resulted in phenotypic variation, especially in flower color (data not shown).

In conclusion, here we report a fast protocol for African violet regeneration from leaves that can provide a reliable tissue culture system for commercial propagation. The protocol is highly efficient, time-saving and genotypeindependent, and is applicable to other tissues: leaf petioles, internode segments, and root explants.

\section{Acknowledgments}

This research was supported by the Azarbaijan Shahid Madani University and the Biotechnology Development Council of the I. R. of Iran.

\section{References}

Ahmadabadi M and Bock R (2010) Development of a highly responsive leaf-based regeneration system for Peperomia species. Turk. J. Bot. 34 : 329-334.

Bilkey PC and Cocking EC (1981) Increased plant vigor by in vitro propagation of Saintpaulia ionantha Wendl., from subepidermal tissue. Hort. Sci. 16 : 643-644.

Cooke RC (1977) Tissue culture propagation of African Violet. Hort. Sci. 12 : 549.

Daud N and Taha RM (2008) Plant regeneration and floral bud formation from intact floral parts of African violet (Saintpaulia ionantha $\mathrm{H}$. Wendl.) cultured in vitro. Pak. J. Biol. Sci. 11 : 1055-1058.

Daud N, Taha RM and Hasbullah NA (2008) Studies on plant regeneration and somaclonal variation in Saintpaulia ionantha Wendl. (African violet). Pak. J. Biol. Sci. 11 : 1240-1245.

Hoshino Y, Nakano M and Mii M (1995) Plant regeneration from cell suspension-derived protoplasts of Saintpaulia ionantha Wendl. Plant Cell Rep. 14 : 341-344.

Lincy A and Sasikumar B (2010) Enhanced adventitious shoot regeneration from aerial stem explants of ginger using TDZ and its histological studies. Turk. J. Bot. 34 : 21-29.

Linsmaier EM and Skoog F (1965) Organic growth factor requirements of tobacco tissue cultures. Physiol. Plant. 18 : 100-127.

Mithila J, Hall JC, Victor JM and Saxena PK (2003) Thidiazuron induces shoot organogenesis at low concentrations and somatic embryogenesis at high concentrations on leaf and petiole explants of African violet (Saintpaulia ionantha Wendl). Plant Cell Rep. 21 : 408-414.

Molgaard JP, Roulund N, Deichmann V, Irgens-Moller L, Andersen SB and Farestveit B (1991) In vitro multiplication of Saintpaulia ionantha Wendl. by homogenization of tissue cultures. Scientia Hort. 48 : 285-292. 
Montero-Cortes M, Saenz L, Cordova I, Quiroz A, Verdeil JL and Oropeza C (2010) GA3 stimulates the formation and germination of somatic embryos and the expression of a KNOTTED-like homeobox gene of Cocos nucifera (L.). Plant Cell Rep. 29 : 1049-1059.

Riou-Khamlichi C, Huntley R, Jacqmard A and Murray JA (1999) Cytokinin activation of Arabidopsis cell division through a D-type cyclin. Science 283 : 1541-1544.

Sahai A, Shahzad A and Anis M (2010) High frequency plant production via shoot organogenesis and somatic embryogenesis from callus in Tylophora indica, an endangered plant species. Turk. J. Bot. 34 : 11-20.

Shukla M, Sullivan JA, Jain SM, Murch SJ and Saxena PK (2013) Micropropagation of African violet (Saintpaulia ionantha Wendl.). Methods Mol. Biol. 11013 : 279-289.

Smith RH and Norris RE (1983) In vitro propagation of African Violet chimeras. Hort. Science 18 : 436-437.

Srejović V and Nešković M (1985) Effect of gibberellic acid on organogenesis in buckwheat tissue culture. Biol. Plant. 27 : 432-437.

Start ND and Cumming BG (1976) In vitro propagation of Saintpaulia ionantha Wendl. Hort. Sci. 11 : 204-206.

Sunpui W and Kanchanapoom K (2002) Plant regeneration from petiole and leaf of African violet (Saintpaulia ionantha Wendl.) cultured in vitro. Songklanakarin J. Sci. Technol. 24 : 357-364.

Thorpe T and Meier D (1973) Effects of gibberellic acid and abscisic acid on shoot formation in tobacco callus cultures. Physiol. Plant. 29: 121 - 124.

Verstraeten I, Beeckman T and Geelen D (2013) Adventitious root induction in Arabidopsis thaliana as a model for in vitro root organogenesis. Methods Mol. Biol. 959 : 159-175.

Weatherhead MA, Grout BWW and Short KC (1982) Increased haploid production in Saintpaulia ionantha Wendl., by anther culture. Scientia Hort. 17 : 137-144.

Winkelmann T and Grunewaldt J (1995) Genotypic variability for protoplast regeneration in Saintpaulia ionantha (H. Wendl.). Plant Cell Rep. 14 : 704-707. 